Yasmin M. El-Sayed

\title{
Intentional Coherence in Literary Dialogue
}

Yasmin M. El-Sayed

University of Benha, Benha

\section{Abstract:}

The present paper investigates coherence in dialogue with special focus on written literary dramatic dialogue. One major source of dialogue coherence is participants' intentions. Coherence represents the integrity and coordination of intentions that are imputed to dialogue participants. The study employs Dialogue Macrogame Theory (DMT) as an analytical framework for describing the organization, structure, and coherence of dialogue.

Key words: Coherence, Dialogue Macrogame Theory (DMT), Participants' Intentions, Dialogue Games.

\section{1-Introduction:}

Language performs two significant functions: first, representation and processing of information about the world and second, information transference between language users. In other words, language is the tool of representing thought, which helps in guiding and arranging actions. This use of language as a means of representation and action necessitates well formedness as a prerequisite.

Dialogue is a conversational activity (or verbal interaction) between two participants where language is the medium of communication. Participants use both linguistic forms as well as non-verbal signals. Dialogue is not structured as merely a sequence of scattered messages that are produced by speakers and received and decoded by addressees. Rather, utterances are arranged into adjacency pairs which, whatever the form that they take (typed, spoken, or produced manually using sign language), "are contingent upon one another such that interpretation depends very much on context" (Brennan, 2013, p. 1).

One major source of dialogue coherence is the intentions of the dialogue participants. It is attained through "the way that the conventions of dialogue cause the participants to adopt and dismiss groups of intentions. Grouping of intentions is the foundation for coordination of the activities of dialogue participants" (Mann, 2002b, p.131).

The present paper is concerned with investigating the concept of coherence in dialogue, with a particular focus on literary dramatic dialogue. The basic guiding principle is that the intentions (goals) and strategies of dialogue participants give rise to the selection of employed speech acts and topics, which, in turn, allow for the dialogue to be structured in a certain way. Therefore, the notion of 'cooperative dialogue game', "in which two players produce speech acts to transfer relevant information with respect to their commitments" (Beun \& van Dijk, 2007, p.365), will be embraced. 


\section{2- Objectives of the study:}

The paper aims to achieve the following objectives:

1- Application of Dialogue Macrogame Theory (DMT) to literary dramatic dialogue.

2- Examination of the role of subject matter and situation in shaping dialogue participants' intentions.

3- Investigation of literary dialogue structure as a form of dialogue.

4- Exploration of integrity of intentions and their representation in dialogue coherence.

\section{3- Methodology:}

The approach adopted for the analysis focuses on a significant unit of description of discourse called 'dialogue game', where language is compared to a game in which the participants are the palyers of the game and the outcome of using the language is the payoff (gain or loss). The concept "poses a clear-cut characterization of well-formedness of discourse ... A discourse is coherent if it can be extended into a wellformed dialogue game" (Carlson, 1982, p.11).

This approach is significant for two reasons. First, it serves to establish a link between language and the reality interpreted, described, and transferred by it. In other words, the language game consists of the language and the actions into which it is woven. Thus, language game brings into focus the fact that using language, as in dialogue, is part of an activity, or a form of life. Second, dialogue game is closely related to the goal-oriented character of language use.

The analysis follows the following steps:

1) Outlining the situation, circumstances, language, and immediate culture underlying the dialogue.

2) Dividing the dialogue into turns, or finer divisions such as sentences.

3) Examining the participants' intentions lying behind each turn through examining the turns of both the sender and the receiver. Identification of intentions is helpful for recognizing the stream of the dialogue. 


\section{Yasmin M. El-Sayed}

4) Fitting DMT definitions to each turn, i.e., by drawing on the participants' individual goals and joint goals, deciding whether a turn is a macrogame or a unilateral.

\section{4- Data source:}

The data of analysis consist of one-act play by the Egyptian dramatist Tawfiq Al-Hakim. The selected play is entitled "Amam Shibbak Altathakir" (In Front of the Box Office). The dialogue throughout the play takes place between TWO characters, namely "He" and "She".

\section{5- Background:}

\section{5-1- Dialogue:}

Dialogue is a basic form of language use and communication. It is a fundamental and constitutive part of everyday social setting. Dialogue is "the flow of meaning between or among speakers ... A form of communication from which something new emerges; participants have a relaxed non-judgmental curiosity with the aim of seeing things as freshly and clearly as possible" (Bohm, 1996, p. ix). It is conceived as "a linear alternating sequence of symbolic elements, e.g. greetings and acknowledgements, or utterances between two participants who alternately play the role of sender and receiver" (Beun \& van Dijk, 2007, pp. 356 - 366). Coordination of content and process is an essential requirement for dialogue to move forward.

Specific constraints and conditions support "expected and permissible contribution which provides the foundation of interlocutors' meaningful exchange and effective coordination" (Mills \& Gregoromichelaki, 2010, p.17). The cultural and linguistic conventions, the personalities and knowledge of the participants as well as their social histories and lives are instances of conditions.

Communicative acts are "the primitive-level actions that all joint activities consist of" (Clark, 1996, p.625). The production and interpretation of these communicative acts are coordinated via a signaling system which encompasses purely linguistic signs in addition to a complex set of facial expressions, gestures, and shared awareness of actions and objects in a shared environment. Therefore, participants can interpret the signs of the signaling system by relying on convention plus common ground. Clark (1996), also, states that "each joint signaling event includes a presentation phase, in which the initiator presents a contribution, and an acceptance phase, in which the other conversants indicate the degree to which they understand and accept or reject that contribution" (p. 625). 
Literary dialogue is different from natural dialogue, or conversation. Literary dialogue is not, in reality, mediated by the characters/participants present in it. Rather, it is mediated by the narrator "who arranges the story for us to read" (Rauma, 2004, p.14). Dialogue in a literary work is a narrative mode used by the writers to demonstrate their objectivity and to masque their presence in the literary work. In other words, the writer attempts to be objective and to convince the reader that it is not he who speaks. Thus, literary dialogue is mimetic; it is an imitation of the real-life dialogue. It is highly stylized and scripted.

According to Palmgren (1986, p.205), literary dialogue is a significant narrative mode that performs several functions. Dialogue is related to the literary situation and personae. It presents the situation and leads to another created situation. It advances the plot and moves the narration forward. Besides, it unfolds and exchanges thoughts and information. It lays out the characters' disposition, thoughts, motives, and attitudes towards life (Palmgren, p.399).

\section{5-2- Participants' Intentions:}

Dialogue is intended to achieve collective or social goals/ends. It is "an exchange of speech acts between two partners [or more] in turn-taking sequence aimed at a collective goal" (Walton, 1992, p.133). Each agent/participant starts the dialogue with certain intentions and knowledge in the context of a certain state of the world. Thus, the dialogue is "a goaloriented process, submitted to joint action and an interactive process, where language is both the aim and the means, between human agents evolving in a socio-economic world" (Caelen \& Xuereb, 2014, pp.284$85)$.

Communication between the participants is the product of planning process to achieve certain goals. In other words, each performs a sequence of mental activities based on some type of reasoning mechanism designed to accomplish some goal state, and are therefore considered as a prerequisite to action. The utterances are regarded as actions that assist in achieving some sort of communicative effect.

Understanding the dialogue relies not only on understanding the informational part of the utterance, but also on the inference of each other's plans and goals. The reason behind communication problems is that either participants' intentions are badly, or not adequately, recognized or when sentence analysis fails; "the speaker will form intentions based on the goals and then act on these intentions producing utterances. The hearer will then reconstruct a model of the speaker's intentions upon hearing the utterance" (Traum \& Allen, 1994, p.1) 


\section{Yasmin M. El-Sayed}

Participants' intentions play a central role in explaining discourse production and interpretation. First, the participants' intentions lead to selecting types of speech acts, and consequently, the dialogue structure is affected. Second, discourse is dialogic not only because speakers take turns, but also because its participants are in a state of tension, even conflict, to display and achieve their intentions in a way that affects the structure of the discourse. Likewise, intentions are closely related to, and affected by, the dialogue situation. In other words, "situation strongly limits what can be accomplished, and may also constrain what can be said" (Mann, 2002a, p.114).

\section{5-3- Dialogue coherence:}

Coherence is defined as "the quality of being logically integrated, consistent, and intelligible ... It is a kind of impression that arises (or not) in a person who attempts to understand particular language use. Generally, it is not language dependent" (Mann, 2002a, p.109). Simply, it means that "parts fit together well so that it is clear and easy to understand" (Sinclair, Fox, Bullen \& Manning, 1987, p.265).

In dialogue, the utterances are not separate independent segments or simple strings of words. They form coherent structures of conversational units. Utterances are performing communicative actions such as requesting, informing, suggesting, confirming and so forth. "Such acts enable preceding expressions to create a singular, ordered world ... Among the common dialogic inputs contributing to coherence issue, and providing answers to preceding questions" (Gergen, Gergen \& Barrett, 2004, p. 42).

Dialogue coherence is the outcome of a dynamic process between participants as they are engaged in a permanent, continuous process of negotiation of coherence. Their verbal and non-verbal exchanges are employed to achieve an end: "A dialogue is said to be coherent when the employed speech acts contribute to the participants' collective goal" (Walton, 1992, p.133)

Dialogue coherence is attributed to "integrity of intentions that, in the process of interpretation, are imputed to the text creator [the dialogue participants]" (Mann, 2002a, p.110). This integrity is achieved through "consistency, sequential continuity, and apparent completeness of the imputed intentions and representation in language" (p.110). In other words, "each utterance is intended to mean something in the direction of achieving a goal in which the conversational actors mutually believe there is interest" (Placintar, 2007, p.295). Rocci maintains that "the role of the communicative intention of the speaker is taken up by the joint goals that the participants want to achieve together through the dialogue" (2005, p.104). 


\section{6- Theoretical Framework:}

\section{6-1- Introductory:}

DMT is the method employed for describing the organization, and consequently the coherence, of literary dramatic dialogue. It is a method proposed by William C. Mann to describe the coherence of dialogue. DMT provides a descriptive account of natural dialogues. It makes explicit the organization, connectedness, and coherence of dialogue as it describes the intentions of dialogue participants and identifies them with the various acts in the interaction. In this framework, dialogue coherence arises from the intentions of the dialogue participants. Further, DMT assumes that dialogue situations are not alike; that is why the dynamics occurring in the dialogue differ. Dialogue games "define the cooperative dimension of the interaction and can be analyzed in terms of joint goals as well as in terms of joint commitments of the participants" (Ibid.).

DMT is a successor to another former theory called "Dialogue Game Theory" that was developed at USC-Information Sciences Institute (ISI) in the 1970s and 1980s. A research team studied natural dialogue with an interest in applying the results to human-computer interaction. Reports on the research were published in a paper by William C. Mann in 1988 entitled "Dialogue Games: Conventions of Human Interaction". DMT differs from its predecessor in that it has the ability to "describe substantially more dialogues and it identifies kinds of mechanisms not included in the predecessor" (Mann, 2002b, p.129).

DMT sets a group of assumptions about dialogue that can be briefed in the following points:

1- Dialogue situations are not alike.

2- Dialogue coherence arises from the intentions of the participants. The intention may represent an intended action or an intended outcome or a combination of both.

3- Dialogue participants will hold hierarchic goal structure.

\section{6-2- DMT Conventions \& Constructs:}

DMT consists of two kinds of functional structures identified below:

\begin{tabular}{|c|c|c|c|}
\hline Name & Function & $\begin{array}{c}\text { Number of } \\
\text { participants }\end{array}$ & Recursive? \\
\hline Macrogames & $\begin{array}{c}\text { Jointly pursue the } \\
\text { goals of the } \\
\text { participants }\end{array}$ & 2 & Yes \\
\hline Unilaterals & $\begin{array}{c}\text { Pursue on or more } \\
\text { goals of one } \\
\text { participant }\end{array}$ & 1 & No \\
\hline
\end{tabular}

Table (1): DMT Basic Constructs (Source: www.bcf.usc.edu/ billmann/dialogue/dg-parts.htm) 


\section{6-2-1- Macrogames:}

The basic organizing principle of DMT is the macrogames. They are regarded as "conventions of the language of the dialogue, and therefore allows the possibility of cultural variation" (Kreutel \& Mann, 2003, p. 60). A macrogame definition consists of certain aspects (a list of identified macrogames is included in Appendix (1)). They are represented in Table (2) below:

1- Goal of the responder $(\boldsymbol{R})$ : this means the goals that the responder must personally seek.

2- Joint goals: this means the outcome that will be jointly sought by initiator (I) and responder (R). In other words, it is a goal that is known and actively pursued by both parties. The goals of both the responder and the initiator do not only complement each other, they are also supportive of their joint goals.

3- Type: this means the full name and the abbreviation, e.g. macrogame full name Information Seeking, abbreviated as (IS).

4- Content: this refers to the information.

\begin{tabular}{|l|l|l|l|}
\hline $\begin{array}{l}\text { Name of } \\
\text { Macrogame }\end{array}$ & Joint Goal & $\begin{array}{l}\text { Goal of Initaitor } \\
\text { (I) }\end{array}$ & $\begin{array}{l}\text { Goal of } \\
\text { Responder (R) }\end{array}$ \\
\hline
\end{tabular}

Table (2): Constituents of Macrogame Definition

The course of the dialogue is both controlled and coordinated by participants' intentions (goals) through particular kinds of actions. Intentions can be introduced, pursued, dismissed, or acted upon through the participants' acts in the dialogue. A participant can propose that a set of goals be made active or made inactive. The negotiation metaphor 'bidding a game' is employed.

The initiator (I) bids a game (bg) and the responder (R) either accepts the bid of the game (ag) or rejects the bid ( $\mathrm{rg}$ ). When a bid of the game is accepted, then the game is open. Either participant can bid termination of the game (bt), and the other participant accepts the termination (at) or rejects it (rt). Both bidding and accepting (or rejecting) a game are always implicit. Accomplishment of joint goals marks the end of the game. Likewise, abandoning the goals of the game suggests accepting termination. The scope of the game is "the entire interval during which it is in use, including the initial bid of the game and the final acceptance of termination" (Mann, 2002b, p.132). The possible actions, along with their abbreviations, that can be involved in a game are listed below: 


\begin{tabular}{|c|c|}
\hline \multicolumn{2}{|c|}{ Game Acts } \\
\hline Name of Game Act & Abbreviation \\
\hline Bid a game & $\mathrm{bg}$ \\
\hline Accept a game & $\mathrm{ag}$ \\
\hline Reject a game & $\mathrm{rg}$ \\
\hline Bid termination of a game & $\mathrm{bt}$ \\
\hline Accept termination of a game & at \\
\hline Reject termination of a game & $\mathrm{rt}$ \\
\hline
\end{tabular}

Table (3): Game Acts (Source: Mann, 2002b, p.134)

Two significant points should be mentioned. First, if a bid to initiate a game is rejected, then the game never becomes open, e.g. as when the initiator offers information and the other party does not need. Second, "occurrences of games can contain occurrences of other games or the same game within their scope" (p.133). This is known as 'embedding' of game. In the analysis, game embedding is shown by a column called 'depth column' which indicates the hierarchical depth of embedding. For example, the main game will be shown in depth column (1). If there is a game embedded within the main game, it will be shown in depth column (2) and so forth.

\section{6-2-2- Unilaterals:}

Unilaterals are an integral class of actions that do not require goal pursuit and are generally confined to a single turn (but can possibly be extended over more than one turn). They are part of the interaction and are performed by one participant. Unilateral actions include performing an action, informing, suggesting an action by the opposite party, raising rhetorical questions and directly abandoning them for the pursuit of dialogue goals, stating an assessment of an idea, promising, and directing or commanding. Other major classes of unilaterals include the following:

1- Politeness: for example, "thank you".

2- Media Management: this group is used to initiate, maintain, and terminate the interaction. Examples include greetings such as 'Hello' or self-identification such as 'I am ...'.

3- Acknowledgement: this group includes short utterances indicating that the speaker of the acknowledgement is positive of what is being expressed. Examples include 'Ok', 'I see', or 'mmm'. 
Yasmin M. El-Sayed

The following table shows the main differences between macrogames and unilaterals:

\begin{tabular}{|c|c|}
\hline \multicolumn{1}{|c|}{ Macrogames } & \multicolumn{1}{c|}{ Unilaterals } \\
\hline \multicolumn{1}{|c|}{ Collaborative } & \multicolumn{1}{c|}{ Non-collaborative } \\
\hline Requiring goal-pursuit & \multicolumn{1}{|c|}{ No joint goal being pursued } \\
\hline $\begin{array}{l}\text { Their scope can be long or short } \\
\text { intervals }\end{array}$ & $\begin{array}{l}\text { Their scope is confined to a single } \\
\text { turn }\end{array}$ \\
\hline
\end{tabular}

Table (4): Distinction of Macrogames and Unilaterals

\section{6-3- DMT analysis \& annotation:}

DMT analysis can be described as "a human activity". The analyst is a person who relies on several kinds of social, cultural, and technical knowledge in order to derive and exercise judgment of the dialogue.

The analysis involves SUBJECTIVE human judgment. It is about what the analyst thinks plausible in this moment of interaction, i.e. "the analyst saying (within the DMT framework that was defined before the analysis began, I see this as the most plausible account" (wwwbcf.usc.edu). Throughout the analysis, the analyst is continually trying to find an answer to the question: "What are the participants plausibly doing now?"

DMT analysis is an assertion by the analyst that certain macrogame and unilateral definitions have been applied to the dialogue in a particular way. The completed analysis is said to be successful if it gives an account for every element of the dialogue. Likewise, it is called partially successful if there are some parts or elements that cannot be accounted for. In other words, dialogues can be fully analyzed, others are partially analyzed and some cannot be analyzed even in part.

The analysis involves two subsequent dependent steps, but before starting the analysis, the analyst needs to know certain information about the dialogue:

1- The circumstances of the dialogue, occasion of talk, and something about the immediate culture, language, and organizational context need to be known.

2- Whether the participants have interacted before, and the outcomes of the most recent interaction (relationships, obligations, fixed knowledge) need to be known. (www-bcf.usc.edu)

Some division of the dialogue into units is needed before beginning the analysis. The unit of analysis is the turn, i.e. "an interval of expression by a single participant" (www-bcf.usc.edu), though finer divisions can be used. The key tool for the analysis is Excel. This program has the ability 
to create, display and manipulate texts, the symbolic annotation, and the analysis diagrams.

The analysis involves applying DMT definitions to dialogue units. The used approach is called 'Moment of Use' approach. "The DMT analyst needs to look at not only each particular utterance and its prior context, but also the immediately succeeding utterances by the other party, how it was interpreted up to the point when the speaker begins to speak again" (www-bcf.usc.edu).

\section{7- Analysis:}

\section{7-1- Introductory:}

The data of analysis consist of one-act play entitled "Amam Shibak Al-Tathakir" (In Front of Box Office) by the Egyptian playwright "Tawfiq Al-Hakim". Tawfiq Al-Hakim occupies the apex position in the modern Arabic drama as he is considered to be the pioneer and founder of the domain in the Arab world.

He was born in (1898) in Alexandria. Diverse sources helped shaping Hakim's interest in literature. First, both his parents' background helped shape his mentality and interest in literature since his early childhood as his mother was a Turkish aristocrat and his father was Attorney General. Another major source of influence was George Abyad's theatrical performances. They encouraged Al-Hakim to start improvising plays with his friends. Also, he secretly wrote and published a number of plays during his study in the Law School. However, due to the deteriorating status of literature and writers in the 1920s, his father asked him to focus on law study instead.

Travelling and staying in Paris (1925 - 1928) marks the turning point in Hakim's career. He travelled to get a Ph.D. degree in law, but he became interested in the study of dramatic literature of the west, particularly the theatre. He was deeply influenced by the European theatre to start a dramatic theatre in Egypt, but "his works are rooted in Eastern and Islamic culture" (Said, 1997, p.7).

Hakim's plays fall into two groups: social plays and mental/ intellectual/ abstract plays. The former group deals with the social conditions prevalent in Egypt with the aim of reforming them. These plays were published in two volumes: "Masrah Al-Mugtamaa" (Theatre of Society) in 1950 and "Al-Masrah Al-Munawaa" (Manifold Theatre) in 1956.

The latter group deals with more universal and philosophical issues. The plays are basically derived from mythology and religion. This category includes plays such as "Ahl Al-Kahf" (Sleepers of The Cave) in 1933 and "Shaharazad" in 1934. 


\section{Yasmin M. El-Sayed}

\section{7-2- "Amam Shibak Al-Tathakir" (In Front of Box Office):}

\section{7-2-1- Theme \& Situation:}

The play is about TWO main characters "He" and "She". As its name suggests, the whole act takes place in one place outside a theatre in France, more specifically, in front of the box office. From the first line of the play, it becomes clear that the female character "She" works in the box office, and the male character "He" is a customer who comes to the box office. The context suggests that "He" wants to buy a ticket for a show. Also, the female character "She" does not have a previous encounter with "He".

However, "He" does not request to buy a ticket as it would be expected. Rather, "He" expresses his admiration and love of the box office girl, and wants to know whether she can love him back, or, at least, find a place for him in her heart. "She" seems to be interested in carrying out the conversation. Finally, "He" succeeds in attracting "She" and she is willing, even anxious, to meet him.

\section{7-2-2- Analysis:}

The employed tool for the representation of the analysis is Excel program. The complete analysis of the transcript is displayed in Appendix (2). The unit of division of the transcript is the turn. Also, there are finer divisions of the turn into sentences. The total number of turns is 153 turns. The dialogue is ordered into three subsequent stages: the opening stage, the argumentation stage, and the closing stage. Each of the three stages is illustrated below:

- Stage 1: The opening:

\begin{tabular}{|c|c|c|c|}
\hline $\begin{array}{c}\text { Function of } \\
\text { Stage }\end{array}$ & $\begin{array}{c}\text { Participants' } \\
\text { intentions }\end{array}$ & Situation & Extension \\
\hline $\begin{array}{lr}1- & \text { The } \\
\text { participants } \\
\text { express their } \\
\text { approval or } \\
\text { disapproval of } \\
\text { taking part in the } \\
\text { dialogue that has } \\
\text { a collective goal. } \\
\text { 2- At this stage, } \\
\text { the participants } \\
\text { demonstrate their }\end{array}$ & $\begin{array}{l}\text { 1- "She" wants to } \\
\text { know what "He" } \\
\text { requests. } \\
2 \text { - "He" wants } \\
\text { "She" to get } \\
\text { involved in the } \\
\text { conversation and } \\
\text { to offer his love } \\
\text { for her. }\end{array}$ & $\begin{array}{l}\text { The dialogue is } \\
\text { between the two } \\
\text { main characters } \\
\text { "He" and "She". } \\
\text { "She" is a box } \\
\text { office girl and } \\
\text { stands there } \\
\text { waiting to serve } \\
\text { customers. "He" } \\
\text { approaches the } \\
\text { box office. "She" }\end{array}$ & Turns 1 - 33 \\
\hline
\end{tabular}




\begin{tabular}{|l|l|l|l|}
\hline \multicolumn{1}{|c|}{$\begin{array}{c}\text { Function of } \\
\text { Stage }\end{array}$} & $\begin{array}{c}\text { Participants' } \\
\text { intentions }\end{array}$ & \multicolumn{1}{|c|}{ Situation } & Extension \\
\hline $\begin{array}{l}\text { individual goals } \\
\text { that serve as the } \\
\text { basis of the } \\
\text { dialogue's } \\
\text { collective goal. } \\
\text { 3- The initial } \\
\text { situation is } \\
\text { presented and the } \\
\text { fundamental } \\
\text { issue of the } \\
\text { dialogue is stated } \\
\text { and agreed upon } \\
\text { by both parties. }\end{array}$ & & $\begin{array}{l}\text { does not have a } \\
\text { former } \\
\text { acquaintance } \\
\text { with "He". "She" } \\
\text { thinks that "He" } \\
\text { is a regular } \\
\text { customer and } \\
\text { inquires about } \\
\text { his request. } \\
\text { However, "He" } \\
\text { has a former } \\
\text { knowledge of } \\
\text { "She". }\end{array}$ \\
\hline
\end{tabular}

In turn (1), as "She" works as a box office girl, she thinks that "He" is a customer. She seeks to start the conversation with "He" to know his request: She: "سيلى بيريب?" (Sir needs?)

The first turn is identified as bidding of Information Seeking game (bg IS). In turn (2), "He" accepts the game (ag) and answers "نسئ يا آنسة، أشكرك!! (Nothing, Miss. Thank you). However, "She" does not get the expected sought informational reply. As a result, "She" asks for clarification of the received information. In turn (3), "She" bids the game of Clarification Seeking (CL), and "He" accepts the game and asserts the same information in turn (6):

Turn (6): "لا شسئ على الإطلاق "(6bsolutely nothing at all)

Now, "He" is certain that "She"'s attention is attracted and she became curious about the conversation with "He". Thus, he wants to find out her response by bidding the game of Response Seeking (RS):

Turn (6): "إيلهشك ذلك أبتها الآنسة؟" (Does this surprise you, Miss?)

"She" accepts the game (ag) in turn \# 7 and expresses her astonishment of the situation:

Turn (7): "بضض الثسئ يا سياى!" (To some extent, Sir)

"She" still insists on knowing what "He" wants. Again, "She" bids the game of Information Seeking (IS). Now, "He" is confident that he drew her attention. He rejects the game (rg) and, simultaneously, asks her about what she wants him to want: "وماذا تريدين أن أطلب؟)"(What do you want me to ask for?). In turn (9), "She" accepts the game and answers that 


\section{Yasmin M. El-Sayed}

"أطلب محكاً مثلكًا! " (Ask for a vacancy for instance!)

In turns 10 through 25, "He" and "She" are seeking and offering information to each other. "He" tells "She" that she does not have a vacant place. "She", on the other hand, affirms the opposite, according to the control panel in front of her. In turn (25), "She" assesses the ideas presented by "He" about vacant places as weird and unfamiliar to her. Thus, her comment is identified as a Unilateral of Assess type: هذا" (عجبي!!(This is weird!).

"He", repeatedly, asks "She" whether she has a place for him in her heart. Thus, turns (26), (28) and (30) are identified as bidding of Information Seeking game. "She" evades the answer. Thus, turns 27, 29, and 31 are identified as rejecting the game (rg). Therefore, "He" did not achieve his goal.

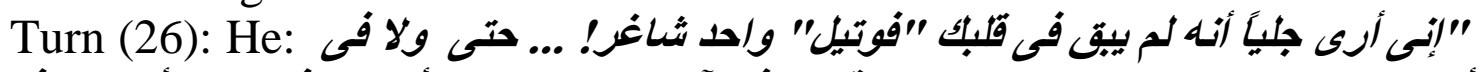
أعلى "التياترو" .. حتى ولا مكان للوقوف فى آخر الصفوف ... ألبيس كنلك؟ ... أليس هذا فالت

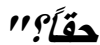

I can clearly see that there is no single vacant "fauteuil"... not even at the roof of the "Theatre" ... not even a place for standing at the end of the lines ... Isn't it? ... Isn't that true?)

Turn (27): She: "دعابة طريفة! "... (Nice joke!)

By the end of this stage, "He" has a hidden goal of attracting "She", and knowing if she has a place for him in her heart, has been exposed and attained by "She". "He" managed to draw her attention and got the opportunity to talk to her and explain his genuine feelings. The types of used games employed to attain his goals are: Information Seeking, Information Offering, and Clarification Seeking.

The opening stage extends from turn (1) through (33). The principal game is Conversation Seeking (CS) that starts with Turn (1) and extends throughout the stage. As it is the principal game, it occupies the first depth (depth 1) and within which other games are embedded within the depths 2,3 , and 4 . The names and codes of the identified games are listed in the following table:

\begin{tabular}{|c|c|}
\hline Code & Game Name \\
\hline CS & Conversation Seeking \\
\hline CL & Clarification Seeking \\
\hline RS & Response Seeking \\
\hline IS & Information Seeking \\
\hline IO & Information Offering \\
\hline Table (6): The identified Games in The Opening Stage
\end{tabular}

The identified unilaterals in the stage are listed in the following table: 


\begin{tabular}{|c|c|c|c|}
\hline \multicolumn{4}{|c|}{ Intentional Coherence in Literary Dialogue } \\
\hline Code & $\begin{array}{l}\text { Unilateral } \\
\text { Name }\end{array}$ & Example & Turn \# \\
\hline POL & politeness & $\begin{array}{l}\text { أثنكرك } \\
\text { Thank you }\end{array}$ & 2 \\
\hline ASSESS & Assess & $\begin{array}{l}\text { هذا عجيب! } \\
\text { This is weird! }\end{array}$ & 15 \\
\hline TELL & Tell & $\begin{array}{l}\text { بلى، بلى .... } \\
\text { Yes, I do. }\end{array}$ & 19 \\
\hline DIR & Direct & $\begin{array}{l}\text { !... صدقينى } \\
\text { Believe me! }\end{array}$ & 20 \\
\hline SUGGEST & Suggest & $\begin{array}{l}\text { فلنتر اهن ... فet's bet ...! } \\
\text { Let' }\end{array}$ & 22 \\
\hline
\end{tabular}

Table (7): Unilaterals in The Opening Stage

The turns between the participants assist in transferring information between them. Both participants attained their desired goals: "He" expressed his real intentions and "She" acquired knowledge of what "He" actually wanted. Therefore, the dialogue type of the opening stage is identified as 'cooperative information-oriented" dialogue:

The main purpose of this type of dialogue is the exchange of information. Moreover, the participants' aim (whether out of personal interest or through external pressure) is to cooperate with each others' requests for information. In such dialogues, participants are not interested in persuading each other of a certain point of view or negotiating a particular course of action. The principal aim is simply the exchange of information. (Piwek, 2007, p.405)

- Stage 2: The argumentation:

\begin{tabular}{|c|c|c|c|}
\hline $\begin{array}{c}\text { Function of } \\
\text { Stage }\end{array}$ & $\begin{array}{l}\text { Participants' } \\
\text { intentions }\end{array}$ & Situation & Extension \\
\hline $\begin{array}{lr}\text { Each party is } \\
\text { supposed } & \text { to } \\
\text { defend } & \text { their } \\
\text { standpoints } & \\
\text { (goals) } & \end{array}$ & $\begin{array}{lr}1- & \text { "He" } \\
\text { expresses } & \text { his } \\
\text { love. } & \text { "He" } \\
\text { desperately } & \\
\text { wants "She" } & \text { to } \\
\text { love him. } & \mathrm{He}\end{array}$ & $\begin{array}{l}\text { "He" is trying to } \\
\text { convince "She" } \\
\text { to love him. } \\
\text { "She" seems to } \\
\text { be interested in } \\
\text { pursuing the }\end{array}$ & $\begin{array}{l}\text { Turn\# } 33-94 \\
\text { Turn\# } 117-134\end{array}$ \\
\hline
\end{tabular}


Yasmin M. El-Sayed

\begin{tabular}{|c|c|c|c|}
\hline $\begin{array}{c}\text { Function of } \\
\text { Stage }\end{array}$ & $\begin{array}{c}\text { Participants' } \\
\text { intentions }\end{array}$ & Situation & Extension \\
\hline & $\begin{array}{l}\text { attempts every } \\
\text { possible means } \\
\text { to persuade her. } \\
\text { 2- "She" attacks } \\
\text { arguments } \\
\text { proposed by } \\
\text { "He" concerning } \\
\text { that she doesn't } \\
\text { have a vacant } \\
\text { place in her } \\
\text { heart. Also, } \\
\text { "She" wants to } \\
\text { know why "He" } \\
\text { wants her to love } \\
\text { him. }\end{array}$ & $\begin{array}{l}\text { conversation. } \\
\text { "She" attempts } \\
\text { her best to } \\
\text { maintain the } \\
\text { conversation } \\
\text { with "He". } \\
\end{array}$ & \\
\hline
\end{tabular}

Table (8): Basic components of the Argumentation Stage

After revealing his real purpose for coming to the box office, "He" has succeeded in drawing her attention. "She" is interested in pursuing the conversation. She directs him not to touch the bet as she considers herself the winner. Thus, turn (34) is identified as bidding a Clarification Seeking game (CL):

He: "كيف?"(How?)

"She" affirms that she has a vacant place in her heart, but it is temporary. "He" is surprised by her talk and wants to make sure that he got her right. Thus, he bids the game of Clarification Seeking in turn (38): مكان للوقوف (A standing room at the end of the lines? How is that?)

However, "He" is not satisfied with the course of the conversation, and since he did not attain his goals, he brings the dialogue to a closing point in turn (50). Thus, the turn is identified as the unilateral (Tell) and the

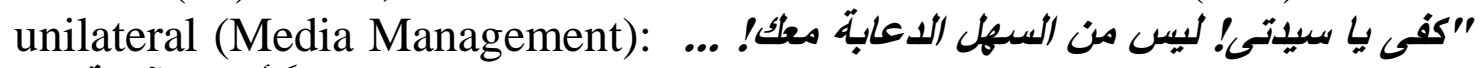
(Enough of that, Madame! ... It is not easy to have a joke with you! ... Goodbye, Miss)

"She" accepts the closing of the conversation and says, in turn (51), "وداعَا يا سيلى! (Goodbye, Sir!). The Conversation Seeking game in depth 1 has ended in turn (51) along with all the embedded games. 
"He" does not give up and attempts for the last time to achieve his goal. He tries to convince her through admiring her beauty in an amusing and funny way. Thus, "He" initiates a new episode of turns, starting with turn (52), where he tells her, without expecting her to respond to him, that a beautiful woman like her should be restrained by a police order. The

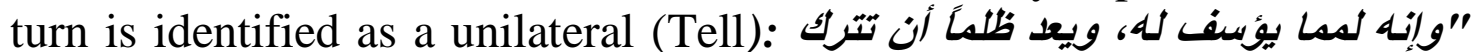

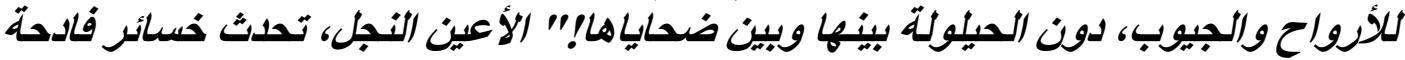

(...it is unfortunate and unfair that the wide eyes are left to cause gross loss to the souls and pockets without stopping them! ...)

However, "She" is attracted by what "He" said. So, she bids the game of Clarification Seeking, and "He" accepts the game in turns (53) and (54). "He" expresses his viewpoint and she participates in the part of the conversation covering turns $(55-67)$.

In turn (68), "He" pursues his original goal of making her love him at any expense. "He" wants to know what he represents to her. He bids the game of Clarification Seeking concerning making sure of his position in "أرقاً أنه حكم على ألا بكون لي غير الوقوف فح آخر الصفوف؟! :

"... (is it really that I'm judged to only stand at the end of the line?! ...)

"She" accepts the game and answers him affimatively.

However, "He" does not give up and wants to get more information about that place in her heart in turns $(71-79)$ through bidding games of Information seeking, Action Seeking, and Clarification Seeking. In each of these turns, "She" accepts the game and helps in achieving the joint goal of each game. This signifies her interest in him and in pursuing the conversation.

In turns (81) and (83), "He" wants "She" to love him. Thus, the turns are identified as bidding the Action Seeking game (AS). She does not accept the game. Rather, she is astonished by his request. Thus, her response in turn (84) is identified as the unilateral (Assess): هذا طلب " "... مد هش! (That is a striking request!! ...). Within the basic Action Seeking game are embedded other related games such as Information Offering and Information Seeking games.

However, their conversation is interrupted by the coming in of a third party, the guard. The guard is the third character in the play. It is a secondary character. For the guard, "He" is just a regular customer. She is not aware of the real dialogue taking place between "He" and "She". The writer introduces the character of the guard at this point of argument to show which side is right and which side is not. The guard wants to have a conversation with "She", so she politely excuses "He" in turn $(95-1)$,

"عفواً سبيدى" (Excuse me, Sir!), which is identified as the unilateral (Politeness) and starts the conversation with "She" saying بونجور " 
" داموازيل (Bonjour, Modemoiselle!) which is identified as the unilateral (Media Management):

"She" opens the conversation with the guard and replies: بونجور مدام" كوزان(Bonjour, Madame Kuzan!), which is identified as the unilateral (Media Management). "She" wants to know what the guard wants. Thus, she bids the game of Information Seeking, and directly abandons the game and does not pursue it as she notices that the guard is wearing black glasses on her eyes. "She" asks the guard whether she is wearing the glasses to hide her beautiful eyes. The turn is identified as the unilateral (Tell):

Turn (96 - 2): She: النت إنن ذات عينين نجلاوين يا مدام! ... ياللعينين الجميلتين  beautiful eyes!)

The guard is surprised by "She's" attitude and wonders whether "She" is mocking her. "She" continues asking the guard unfamiliar questions that make no sense to the guard. The questions are concerned with the guard's putting on the black glasses based on police order. In turn (109-13), the guard wants to know what police order "She" is talking about. The game of Clarification Seeking is bid. "She" does not provide any explanation to the guard. Thus, her reply is identified as rejecting the game:

Guard: "أى أمر بولييس؟" (What Police order?)

She: "إنزعيها واسمعى كلامى! (Listen to me and take them off....!)

The guard got the feeling that "She" is mocking her. Thus, she brings the dialogue to an end in turn (115 - 17), which is identified as containing two unilaterals, (Tell) and (Media Management).

It is noted that while "She" was talking to the guard, Madame Kuzan, about the allegations that were earlier proposed by "He", "She" was occasionally directing her speech to "He", asking for his assessment of the information that "She" is saying. "She"'s intention is to refute "He"'s allegations and to show him that any one, like Madame Kuzan, would not accept these allegations as true. This is exactly what "She" attained by talking to the guard. Thus, turns (105), (108), and (113) are identified as bids of the Response Seeking game. "He" does not reply, so this is considered as rejection of the game: "أليس كنلك با سبياى!" (Isn't that so, Sir?!)

After the guard leaves the scene, "She" desires to pursue the conversation with "He" from where they stopped before the guard came in. In turn (117), "She" asks him about the reason that he wants her to love him. It is identified as Information Seeking game. The bid of the game has an extended scope till turn (134). "She" asserts that she cannot love him, and justifies that by saying that her heart does not belong to her. Thus, turn (125) is identified as bidding Information Offering (IO) game: 


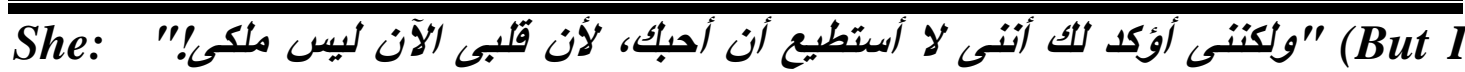
assure you that I can't love you because my heart is not mine! ...)

"He" understands and realizes the offered information and starts negotiating and arguing. Thus, the scope of the information offering game embeds other related bid games such as Information Seeking. The scope extends till turn 134, which marks the end of the stage.

It is worth mentioning that a dialectical shift occurs with the start of the argumentation stage. Dialectical shift occurs when the dialogue participants "begin to engage in a different type of dialogue from the one they are initially engaged in" (Walton \& Krabbe, 1995, p.29). In this stage, the dialogue between "He" and "She" transforms from 'cooperative information-oriented' dialogue into 'persuasion' dialogue. In such a type, the initial situation is conflict of opinions and each party attempts to persuade the other party. In the argumentation stage, "He" and "She" are attempting to win over the other side by finding arguments that defeat its thesis or doubts it. This dialectical shift resulted from the shift of intentions and the shift of the situation.

The dialogue strategies shifted, as well, to accommodate the new emerging type. As the main goal of both participants is to persuade the other of the adopted viewpoint: "He" wants her to love him and does not accept a place at the end of lines and "She" wants him to tell her why she should love him, they attempt to do so through the strategy of Convincing. For example, when "He" tried to alter "She"'s views concerning giving him a temporary place in her heart, he tried to convince her that it is the fault of beautiful women to make men love them and make them suffer.

The following table lists the names and codes of the identified games:

\begin{tabular}{|c|c|}
\hline Code & Game Name \\
\hline IS & Information Seeking \\
\hline IO & Information Offering \\
\hline CL & Clarification Seeking \\
\hline RS & Response Seeking \\
\hline IO & Information Offering \\
\hline
\end{tabular}

Table (9): The identified Games in The Argumentation Stage

The identified unilaterals in the argumentation stage are listed in the following table:

\begin{tabular}{|c|c|l|c|}
\hline Code & $\begin{array}{c}\text { Unilateral } \\
\text { Name }\end{array}$ & \multicolumn{1}{|c|}{ Example } & Turn \# \\
\hline MM & $\begin{array}{c}\text { Media } \\
\text { Management }\end{array}$ & $\begin{array}{l}\text { "مدام Sadame Kuzan } \\
\text { Madil }\end{array}$ & $(116-1)$ \\
\hline
\end{tabular}




\begin{tabular}{|c|c|c|c|}
\hline \multicolumn{4}{|c|}{ Yasmin M. El-Sayed } \\
\hline $\mathrm{ACK}$ & Acknowledge & 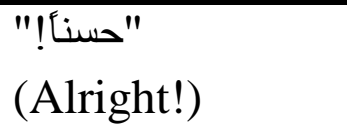 & 90 \\
\hline ASSESS & Assess & $\begin{array}{l}\text { "ليست صـادقة؟!) } \\
\text { (It is not true!) }\end{array}$ & 123 \\
\hline RHET & $\begin{array}{l}\text { Rhetorical } \\
\text { Question }\end{array}$ & $\begin{array}{l}\text { "أمر من؟' } \\
\text { (Whose orders?) }\end{array}$ & $(103-9)$ \\
\hline
\end{tabular}

Table (10): Unilaterals in The Argumentation Stage

- Stage 3: The closing:

\begin{tabular}{|c|c|c|c|}
\hline $\begin{array}{c}\text { Function of } \\
\text { Stage }\end{array}$ & $\begin{array}{c}\text { Participants' } \\
\text { intentions }\end{array}$ & Situation & Extension \\
\hline $\begin{array}{l}\text { It marks that the } \\
\text { end of the } \\
\text { dialogue } \\
\text { Participants' } \\
\text { intentions. They } \\
\text { either have been } \\
\text { fulfilled, } \\
\text { dismissed, or } \\
\text { rejected. }\end{array}$ & $\begin{array}{l}\text { "He" attempts a } \\
\text { final way of } \\
\text { offering his love. } \\
\text { "He" wants her } \\
\text { to meet him at a } \\
\text { restaurant as a } \\
\text { sign of accepting } \\
\text { his love. } \\
\text { "She" does not } \\
\text { want to end the } \\
\text { conversation and } \\
\text { wants him to } \\
\text { know that she is } \\
\text { not going to } \\
\text { accept his love. }\end{array}$ & $\begin{array}{l}\text { "He" and "She" } \\
\text { are still } \\
\text { negotiating the } \\
\text { issue of love. } \\
\text { "He" offers } \\
\text { "She" the } \\
\text { opportunity to } \\
\text { choose either to } \\
\text { love him or to } \\
\text { forget about him. } \\
\text { "She" wants to } \\
\text { know the place } \\
\text { of the restaurant } \\
\text { in order to go } \\
\text { and meet him. } \\
\text { That is why she } \\
\text { needs to get the } \\
\text { information from } \\
\text { Madame Kuzan, } \\
\text { the guard. }\end{array}$ & $\begin{array}{l}\text { Turns } 135-145 \\
\text { Turns } 146 / 1 \\
153 / 8\end{array}$ \\
\hline
\end{tabular}

Table (11): Basic components of the Argumentation Stage

"He" has discussed the matter of love with "She" and, to him, she does not seem to be convinced. So, he ends the conversation. In turn (134), the unilateral Media Management is identified: "والآن إلى الملتقى أريتها الآنسة!!) (Now, Goodbye, Miss!). "She" does not want to terminate the conversation as she got interested in him. Thus, in turn (135), instead of replying (Goodbye, Sir), she bids a new game of Information Seeking: "|تتهضى:" (Are you leaving?). "He" accepts the game, and now, he is sure 
that she is interested. Thus, in turn (138), he bids the game of Information Offering, giving her his address in order to write to him if she is interested

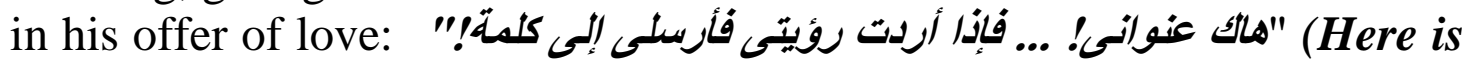
my address! ... If you want to see me, send me a word! ...). "She" recognizes the offered information and accepts the game.

After he leaves, "She" calls the guard to have a talk with her. "She" has a main goal in this conversation, i.e., to get information from the guard concerning the location of restaurant where she is supposed to meet him. Thus, the main game is bid in turn (152 -7). It is identified as Information Seeking game: "الزتعرفين أرين هو مطعم "الأب لويي") (Do you know where "Father Louis" restaurant is?), and the guard accepts the game in turn $(153-8)$ and gives her the address.

\section{8- Conclusion:}

The present paper is an attempt to get a better understanding of dialogue through investigating the concept of coherence in dialogue and its relation to participants' intentions. Dialogue Macrogame Theory (DMT) is the theoretical framework employed as it describes the organization of certain kinds of dialogues. Its constitutive structures are based upon intentions imputed to dialogue participants. The main focus was the application of DMT to literary dramatic dialogue. The data of analysis consist of one-act play by the Egyptian playwright Tawfiq AlHakim.

As an exercised framework, the application of the theory has revealed significant remarks. First, the analysis can be described as successful since every part of the dialogue finds an identified game or unilateral. In other words, the analysis finds an analytic description for every utterance of the dialogue. This is an indication that the dialogue is coherent. Coherence arises from the consistency between the participants' intentions and the situation in which the dialogue takes place. Dialogue situation proved to be a major factor in arranging the intentions and, consequently, helped moving the dialogue forward.

Second, DMT is applied to a dialogue in Arabic, and it proved valid. This is an indication that the theory is not confined to certain languages or restricted to specific linguistic forms. Rather, the theory basically indicates that coherence is dependent upon participants' intentions and the relevant context. In other words, DMT is completely functional and goaloriented.

A third major remark is that literary dramatic dialogue is not different from natural dialogue except for the fact that it is mimetic and stylized. It has the same strategies and systems employed in natural dialogue to help 


\section{Yasmin M. El-Sayed}

attain the participants' goals. Likewise, literary dialogue can be characterized by dialectical shift which results from shift of intentions and situation. Also, the analysis has demonstrated the ability of applying DMT to a wide range of dialogue types. In the present study, DMT proved effective in the analysis of cooperative information-oriented dialogue and persuasion dialogue. 


\section{References}

Beun, R. \& van Dijk, R. M. (2007). Dialogue coherence: A generation framework. Journal of Logic, Language, and Information, 16(4), 365-385.

Bohm, D. (1996). On dialogue. In L. Nichol (Ed.), On dialogue (pp. 647). London and New York: Routledge.

Brennan, S. E. (2013). Conversation and dialogue. In H. Pashler (Ed.), Encyclopedia of the mind. Thousand Oaks, CA: SAGE publications.

Caelen, J. \& Xuereb, A. (2014). Dialogue analysis: Pragmatic and rhetorical aspects. In M. Rebuschi et al. (Eds.), Interdisciplinary works in logic, epistemology, psychology and linguistics (pp. $283-$ 314). New York: Springer.

Carlson, L. H. (1982). Dialogue games: An approach to discourse analysis (Unpublished doctoral dissertation). Massachusetts Institute of Technology, Massachusetts.

Clark, H. H. (1996). Book reviews: Using Language. Computational Linguistics, 23(4), 625-628.

Gergen, K. J., Gergen, M. M., \& Barrett, F. J. (2004). Dialogue: Life and death of the organization. In D. Grant, C. Hardy, C. Oswick, N. Phillips, \& L. Putnam (Eds.), The handbook of organizational discourse (pp. $39-60)$. Thousand Oaks: Sage.

Kreutel, J. \& Mann, W. C. (2003). Analysing bids in dialogue macrogame theory using discourse obligations. Diabruck'03, 59- 66.

Mann, W. C. (2002a). Dialogue analysis for diverse situations. Proceedings of the Sixth Workshop on the Semantics and Pragmatics of Dialogue, UK.

Mann, W. C. (2002b, July). Dialogue Macrogame Theory. Proceedings of the Third SIGDial Workshop on Discourse and Dialogue, Philadelphia.

Mills, G. \& Gregoromichelaki, E. (2010). Establishing coherence in dialogue: Sequentiality, intentions, and negotiations. P. Lupkowski \& M. Purver (Eds.), Aspects of semantics and pragmatics of dialogue (pp. 17 - 24). Poznan: Polish Society for Cognitive Science.

Palmgren, M.-L. (1986). Johdatus kir ja ilisuustieteeseen. Juva: WSOY.

Piwek, P. (2007). Meaning and dialogue coherence: A proof-theoretic investigation. Journal of Logic, Language, and Information 16 (4), pp. $403-421$.

Placintar, E. (2007). Pragmatic interpretation: Conversational coherence. Series Philologica 8 (2), pp. $295-300$. 


\section{Yasmin M. El-Sayed}

Rauma, S. I. (2004). Cinematic dialogue, literary dialogue, and the art of adaptation: Dialogue metamorphosis in the film adaptation of the green mile (Unpublished master's thesis). University of Jyvaskyla, Department of English.

Rocci, A. (2005). Connective predicates in monologic and dialogic argumentation. SComS: Argumentaion in Dialogic Interaction, 97, $97-118$.

Said, A. A. (1997). Tawfiq al-hakim's bank of anxiety: Sounding the alarm. The Gombak Review, 2(1), pp. 6 - 19.

Sinclair, J. M., Fox, G., Bullen, S., Manning, E. (1987). Collins cobuild English language dictionary. London: Collins.

Traum, D. \& Allen, J. (1994). Discourse obligations in dialogue processing. $32^{\text {nd }}$ Annual Meeting of the Association for Computational Linguistics.

Walton, D. N. (1992). Types of dialogue, dialectical shifts and fallacies. In F. H. Van Eemeren et al. (Eds.), Argumentation illuminated (pp. 133-147). Amsterdam: SICSAT.

Walton, D. N. \& Krabbe, E. C. W. (1995). Commitment in dialogue. Albany: State University of New York Press. 
